\title{
PSYCHE.
}

\section{A NEW PARASITE OF THE HESSIAN FLY.}

\author{
BY STEPHEN ALFRED FORBES, CHAMPAIGN, ILL.
}

Parasitism of the winter brood of the Hessian fly has been but rarely and doubtfully reported, and so far as I know, has not hitherto been strictly authenticated. An observation recorded by Prof. Herrick in $184^{1}$, probably referring to the parasite now known as Platygaster herrickii, Pack., implies an abundant development of that species in the hibernating generation of the "fly," but this observation was almost certainly incorrect in some respects, - as has been shown by $\mathrm{Mr}$. Howard, ${ }^{2}$-and has not been verified in this particular.

The breeding of unknown parasites from infested wheat in spring was reported by the writer in $1885 ;^{3}$ but the breeding cage management in this case was not such as to make it certain that these were derived from the Hessian fly. The following instance is, consequently, probably the first to establish clearly the occurrence of this phenomenon.

From a field of wheat sowed after o:ts and corn in the autumn of 1886 , living plants containing numerous puparia of the Hessian fly were sent to me Mar. 15, 1887, by my correspondent Samuel Bartley, Esq., of Edgewood, in southern Illinois. A number

\footnotetext{
1 Herrick, C: E. A brief preliminary account of the hessian-fly and its parasites. (Amer. journ. sci. and arts, $184 \mathrm{r}$, v. $4 \mathrm{I}$, p. $\left.153^{-1} 5^{\mathrm{S}}\right)$, p. 157 .

2 i Ioward, L. O. (3d rept. U. S. entom. comm., 1883 , p. 219 , foot note.)

${ }^{3}$ Forbes, S. A. (14th rept. State entom. Ill., p. 46 , foot-note.)
}

of these puparia were enclosed in a dry vial; and from them seven imagos of Cecidomyia destructor emerged previous to the 23d of April. This vial was not again examined until Oct. 18 , when seven proctotrupid parasites were found in it-all dead. These belonged to the genus Platygaster, as limited by Foerster ${ }^{4}$ and Thomson, ${ }^{5}$ and to a species apparently undescribed.

\section{Platygaster hiemalis, n. s.}

General surface smooth, shining black; head opaque, very slightly pubescent, not cuboid, wider than thorax, nearly twice as wide as long. Temples narrow, vertex not margined, but minutely transversely rugulose. Front also transversely corrugated above the antennae, this corrugation merging in a general irregular lineation of the face. Upper half of front regularly convex, lower with a slight vertical carina commencing between the bases of the antennae. Ocelli not elevated, lateral ones equidistant from the eye and the median ocellus.

Thorax short, deep, very convex, not compressed ; prothorax minutely transversely lineate at the sides; mesothorax shining, ovate, broadest just before wings, dorsum bare in middle, elsewhere with sparse gray hairs, sides more hairy in front. Parapsidal grooves scarcely visible. Scutellum semi-circular, vaulted, nearly hemispherical, without angle or process,

4 Foerster, A. Hymenopterologische studien, heft 2, $1850, p$, I08 and irs.

5Thomson, C. G. Sveriges proctotruper. (Öfvers. af Kongl. vetensk.-akad. förhandl., 1859, v. 16, p. 69-87) p. 83 . 
conspicuously hairy in front and at sides, bare and shining in middle ; separated from mesoscutum by a rather deep transverse groove with two large coarsely punctate and hairy foveae. Dorsal outline of thorax consequently broken at scutellum. Tegulae shining, smooth, slightly embrowned. Metathorax hairy above and on sides.

Abdomen obovate, not narrowed at tip, smooth, shining, except first segment, which is covered with long gray hairs above and beneath, and the tip of the abdomen, which is slightly hairy at posterior edges of segments. Second segment with elongate basal foveae above, and a longitudinal basal groove on each side beneath, slightly concave to the margin, and extending twothirds the length of the segment.
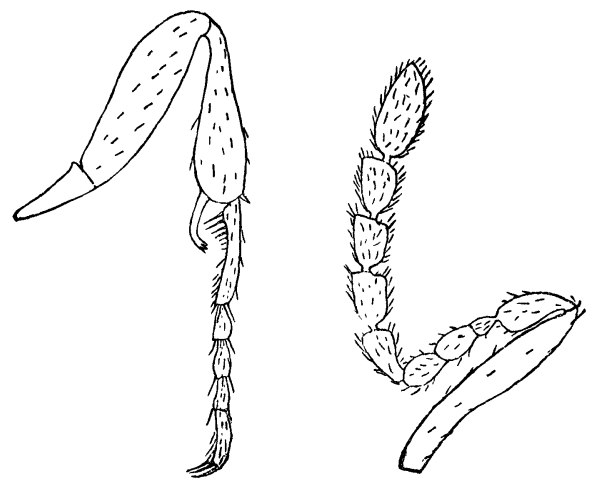

Antennae ten-jointed, black, with scape long, sinuous, and not clavate, and reaching to top of head. Club five-jointed in female, six-jointed in male, not compressed, more hairy than scape and funicle. First joint of latter obovate; second small, one-half to onethird the third,-the latter excurved and obliquely truncate in male, similar to fourth in female. First joint of club obconical, remaining joints, except the last, quadrate, nearly equal in length, about two-thirds as wide as long. Last joint in female ovate, obtuse, not much longer than the preceding: in male narrower, acute, nearly twice as long as preceding.

Head, thorax, and abdomen black throughout. Anterior legs yellowish shaded with fuscous, except coxae and distal joint of tarsi, which are black on all the legs. Middle legs darker, hind legs black, except tarsi and band at upper end of tibia. Upper surface of all the femora black. Wings extending far beyond the abdomen, hyaline, iridescent.

Total length of head and body .94 $\mathrm{mm}$.; fore wings $.84 \mathrm{~mm}$. long, . 35 $\mathrm{mm}$. wide. Head $35 \mathrm{~mm}$. wide, . 85 $\mathrm{mm}$. long; thorax $.36 \mathrm{~mm}$. long, .29 $\mathrm{mm}$. wide, and $\cdot 30 \mathrm{~mm}$. deep. $\mathrm{Ab}$ domen of female $.46 \mathrm{~mm}$. long, .30 mm. wide.

This species differs from Platygaster herrickii (authentic specimens of which Mr. L. O. Howard has kindly sent me) chiefly in its much smaller size, more shining aspect,-due to the absence of the reticulate finish of the surface characteristic of $P$. herrickii, - by the shorter and more vaulted thorax, by the corrugated, narrower, and more convex vertex, and the narrower temples, - the head having a less cuboidal form,-but especially in the parapsidal grooves, which in Platygaster herrickii are very large and distinct, and in $P$. hiemalis are barely visible in the most favorable light.

From $P$. minutus, very briefly described by Lindeman, ${ }^{6}$ it differs in size, and conspicuously so in the proportions of the antennal segments,-Lindeman's species being only $.5 \mathrm{~mm}$. in length, and the antennal scape about twice as long as the first joint of the flagellum.

6 Lindeman, K. Die pteromalinen der hessenfliege, cecidomyia destructor Say. (Bull. Soc. impér. natur Moscou, 1887, no. 1, 177-192.) Separate, p. I2. 

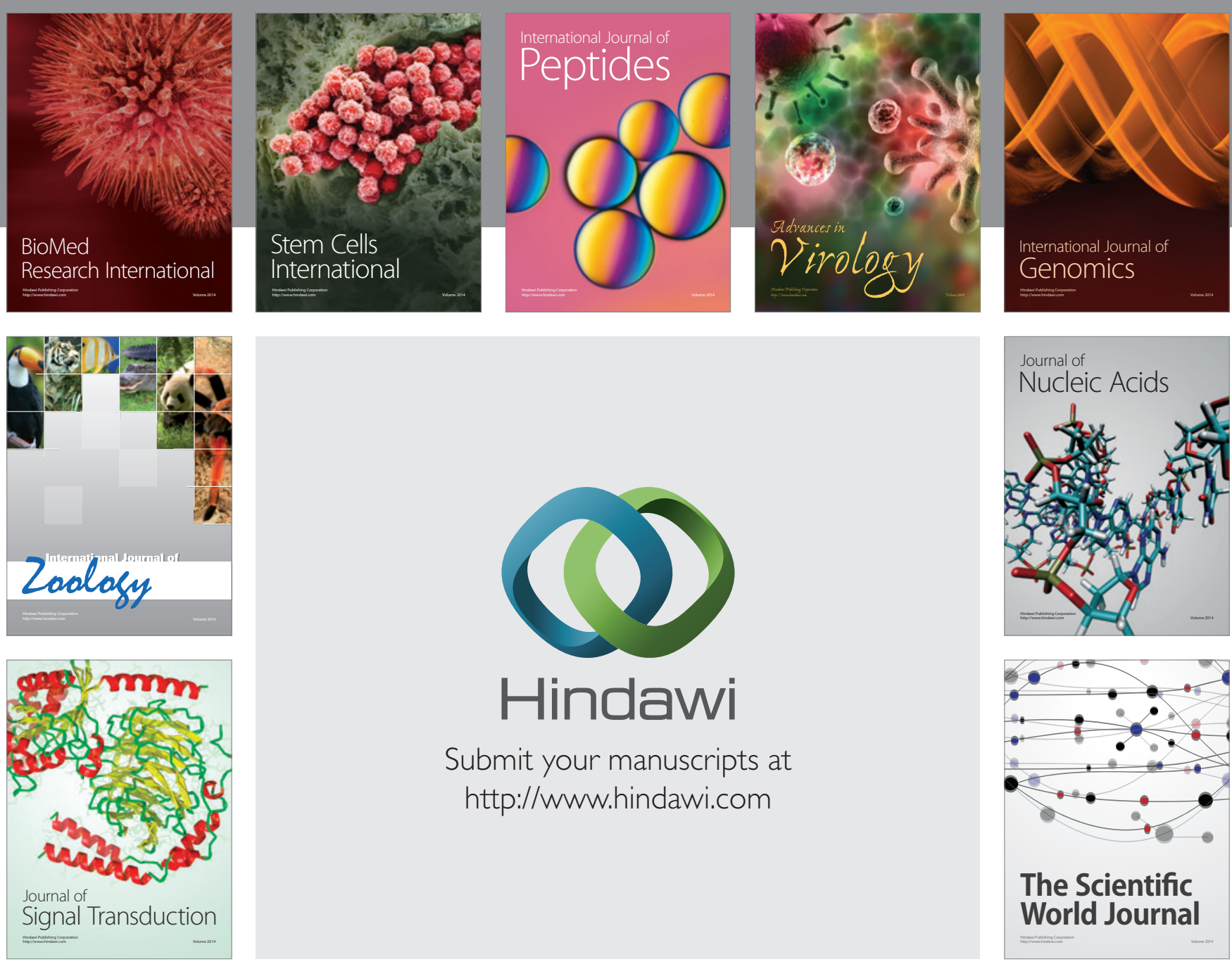

Submit your manuscripts at

http://www.hindawi.com
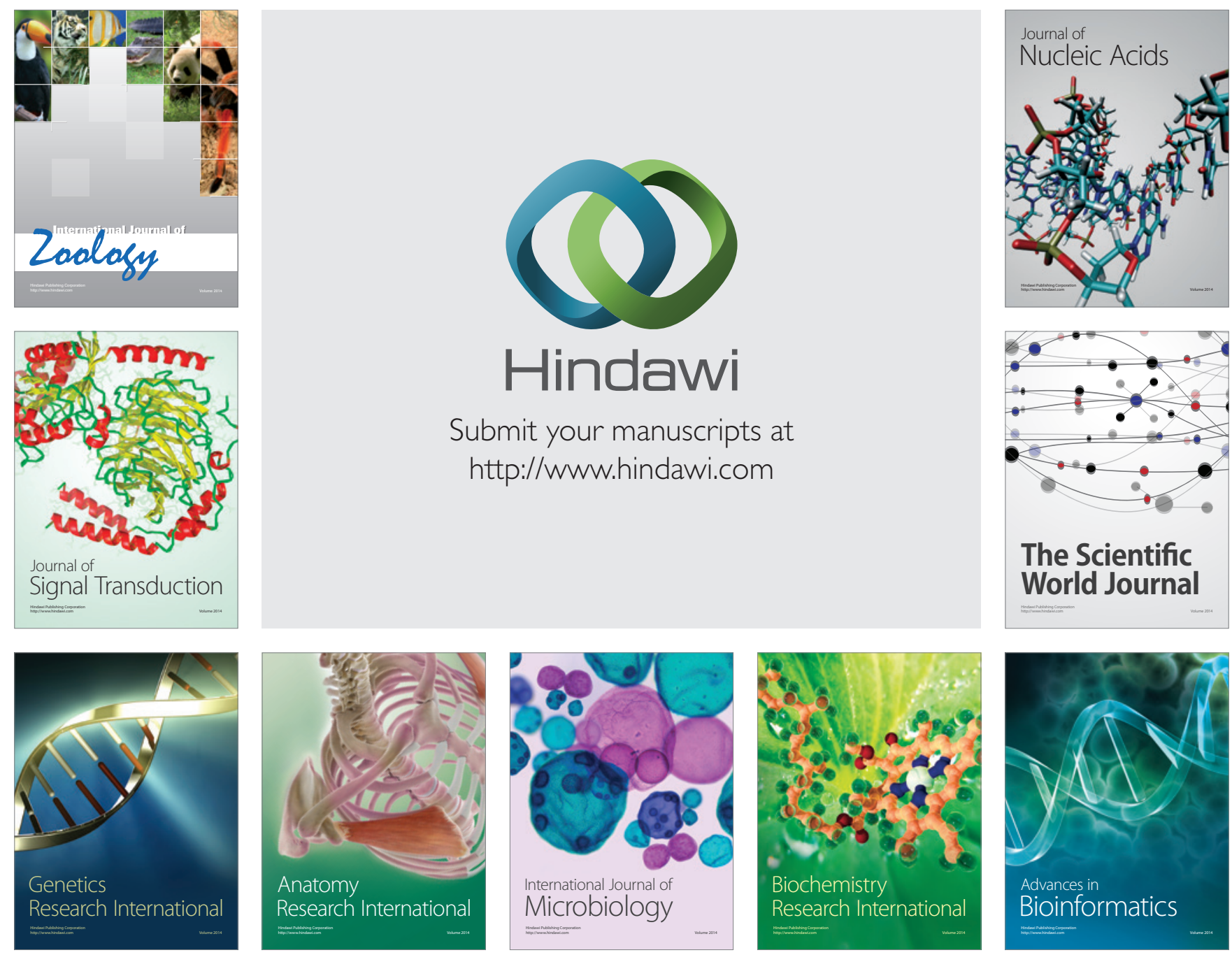

The Scientific World Journal
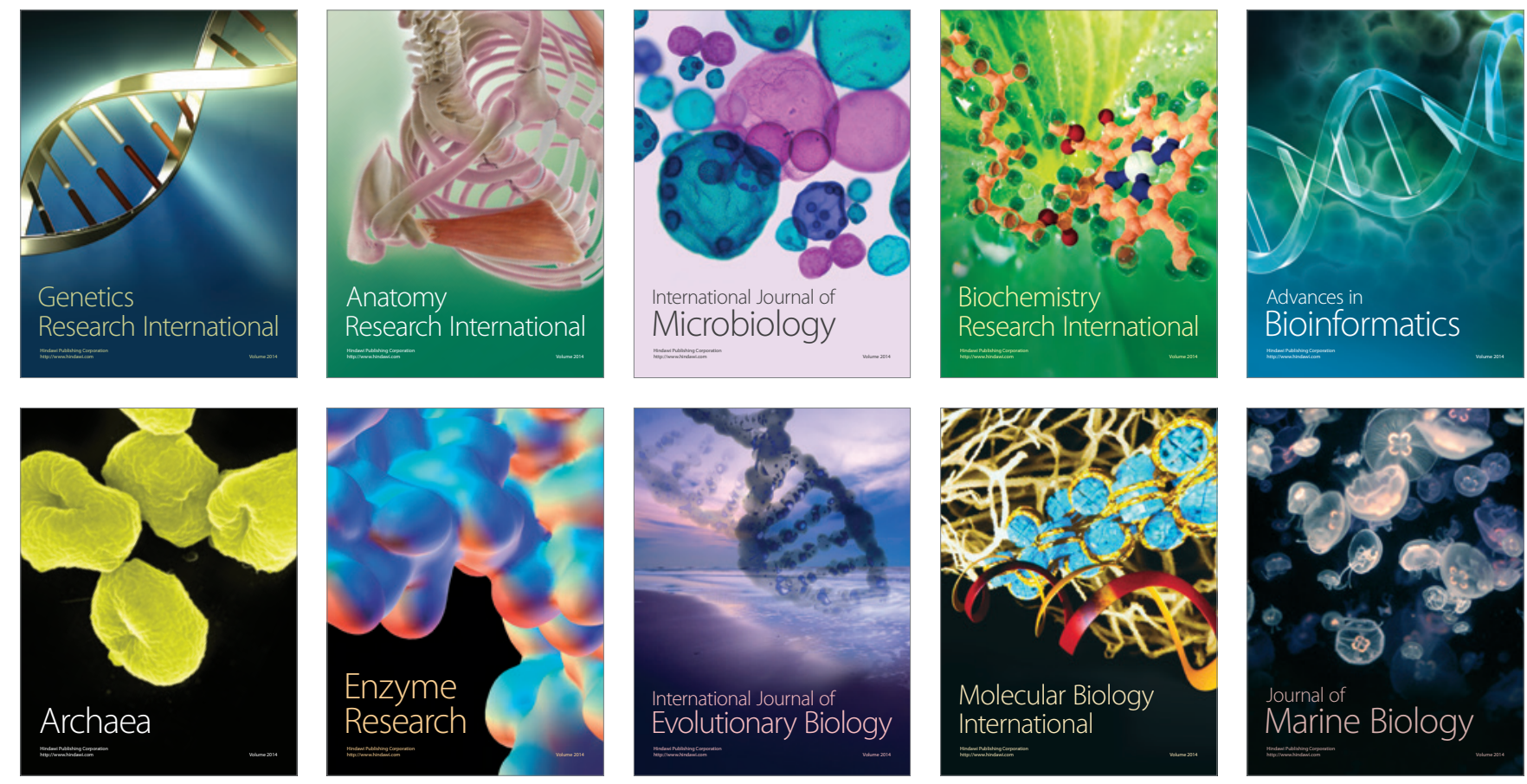